\title{
KASUS-KASUS KEKERASAN DALAM RUMAH TANGGA DAN PENYELESAIAN YURIDISNYA DI PAMEKASAN
}

\author{
Siti Musawwamah \\ (Dosen Tetap pada Jurusan Syari'ah STAIN Pamekasan dan alumni S2 Universitas \\ Narotama Surabaya)
}

\begin{abstract}
Abstrak:
Artikel ini disarikan dari laporan penelitian ${ }^{1}$ yang dilakukan di Pengadilan Negeri Pamekasan dengan 3 fokus penelitian, meliputi bentuk kasus-kasus KDRT, penyebab terjadinya kasuskasus KDRT, dan penyelesaian yuridis kasus-kasus KDRT. Melalui pendekatan hukum normatif dengan jenis penelitian explorative ex-post facto atas produk putusan kasus-kasus KDRT diperoleh temuan, yaitu: (1) bentuk kasus-kasus KDRT berupa kekerasan fisik dan penelantaran rumah tangga yang dilakukan suami kepada istrinya; (2) penyebab terjadinya kasus-kasus KDRT adalah problema relasi suami istri. Suami belum dapat memosisikan istrinya sebagai "mitra" hidupnya, bahkan suami merasa sebagai pihak yang dominan/superior dan sebaliknya istri dianggap sebagai pihak yang inferior; (3) Penyelesaian yuridis kasus-kasus KDRT menunjukkan ketidaknetralan hakim karena hanya memperhatikan kepentingan terdakwa/pelaku. Hakim belum memiliki perspektif jender yang memadai, bahkan masih mengukuhkan, melanggengkan, dan membenarkan budaya patriarki/dominasi suami atas istri.
\end{abstract}

\section{Kata Kunci:}

KDRT, kasus kekerasan, yuridis, dan rumah tangga.

\section{Pendahuluan}

Tindak kekerasan pada tahun-tahun belakangan ini telah menjadi populer dalam realitas aktual kehidupan, terutama setelah memasuki wilayah politik, ekonomi, sosial, budaya, maupun

1 Diadaptasi dari naskah laporan hasil penelitian kolektif yang disusun oleh Siti Musawwamah (ketua tim), Maimun, dan Sakinah (masing-masing sebagai anggota tim) dengan judul Kasus-kasus KDRT dan Penyelesaian Yuridisnya di Pamekasan (Pamekasan: DIPA-STAIN, 2006). 
pemikiran keagamaan. Realitas demikian juga telah masuk dalam wilayah unit sosial terkecil dan eksklusif, yaitu kehidupan rumah tangga yang pada awalnya dibangun atas dasar cinta dan kasih sayang dan dipandu oleh nilai-nilai religiusitas, rasionalitas, dan humanitas-yang secara teoretik seharusnya tidak terjadi "peristiwa" tindak kekerasan di dalamnya. Kenyataannya, justru terjadi sebaliknya. Rumah tangga tidak lagi steril dari perilaku maupun tindakan kekerasan yang secara faktual dilakukan oleh anggota keluarga di dalamnya. Pelaku maupun korbannya berada dalam lingkungan rumah tangga itu, yakni terjadi pada suami, istri, orang tua, anak, sanak-kerabat, dan/atau orang-orang yang menetap di dalamnya.

Dalam kaitan itu, Komnas Perempuan mempublikasikan laporan tentang adanya fakta dan data Kekerasan Dalam Rumah Tangga (untuk selanjutnya disebut KDRT) yang telah terjadi dalam lingkungan eksklusif keluarga. Faktanya selalu meningkat dari tahun ke tahun. Pada tahun 2004, Komnas Perempuan menyebut angka 5.934 kasus KDRT yang ternyata secara kuantitas meningkat dibandingkan dengan tahun-tahun sebelumnya. Tahun 2002 terjadi 3.169 kasus sedangkan tahun 2003 melonjak-naik menjadi 5.163 kasus KDRT. ${ }^{2}$ Data statistik yang relatif lengkap mengenai kasus KDRT di seluruh Indonesia memang belum tersedia, sekurang-kurangnya sangat sulit diakses dan diperoleh.

Walaupun begitu, terdapat sejumlah informasi, fakta, dan data yang berhasil diungkap oleh Lembaga Swadaya Masyarakat (LSM) dan Organisasi Perempuan yang secara khusus menerima pengaduan dan membantu korban KDRT. Mitra Perempuan, misalnya Lembaga Women's Crisis Centre (WCC) yang berkedudukan di Jakarta, menyatakan bahwa selama periode antara tahun 1997-2002 telah menerima pengaduan anggota masyarakat tentang kasus KDRT, yaitu sebanyak 879 kasus yang terjadi di Jakarta, Bogor, Tangerang, Bekasi dan sekitarnya. Tindak KDRT terbanyak dilakukan oleh suami kepada istrinya, yakni 69\%-74\%. Di antara sejumlah kasus itu, hanya $15,2 \%$ yang diselesaikan secara yuridis melalui jalur hukum oleh para istri yang tertimpa tindak KDRT. Selebihnya $(45,2 \%)$ mereka

\footnotetext{
2 N. Saidah, "KDRT bukan Masalah Jender", Al-Wa'ie, No. 66 Tahun IV, (Februari,
} 2006), hlm. 13. 
mengatasinya dengan cara pindah rumah dan 10,9\% sisanya memilih berdiam diri tanpa melakukan upaya apapun.

Rifka Annisa, salah seorang pengurus WCC yang berlokasi di Yogyakarta, juga pernah mempublikasikan laporannya bahwa selama tahun 1994-2000 telah diterima 994 kasus pengaduan kekerasan terhadap istri yang telah dilakukan oleh para suami mereka di Yogyakarta dan Jawa Tengah. Bahkan Menteri Pemberdayaan Perempuan RI menyatakan bahwa terdapat 11,4\% dari 217.000 .000 penduduk Indonesia atau sekitar 24.000 .000 perempuan di pedesaan mengaku pernah mengalami kekerasan. Peristiwa kekerasan yang paling banyak diderita oleh kaum perempuan itu berbentuk KDRT. ${ }^{3}$ Menurut Hussein Muhammad, penanganan kasus-kasus KDRT itu mengalami banyak kendala disebabkan, antara lain, karena masih kuatnya anggapan bahwa KDRT adalah urusan privat atau domestik kerumahtanggaan, dianggap lumrah terjadi, dan bahkan dibela oleh pandangan keagamaan sebagian pihak serta ditoleransi oleh tatanan budaya masyarakatnya. ${ }^{4}$

Meskipun demikian, tidak berarti bahwa penanganan kasuskasus KDRT tersebut tidak pernah menuai hasil. Sekurangkurangnya, terdapat data dari Laporan Tahunan Pengadilan Agama yang dapat dijadikan bukti bahwa korban KDRT telah menempuh jalur hukum dalam bentuk pengajuan gugatan perceraian guna mengakhiri kemelut dan problema kerumahtanggaan mereka. ${ }^{5}$ "Keputusan sulit" yang dilakukan oleh para pihak (istri atau suami yang tertimpa persoalan KDRT) untuk menyelesaikan kasusnya dalam bentuk pengajuan gugatan perceraian di Pengadilan, sesungguhnya merupakan alternatif dari berbagai pilihan untuk mencari solusi dari kemelut problema kerumahtanggaan mereka yang rumit dan memuncak.

Dalam Laporan Tahunan Pengadilan Agama Pamekasan disebutkan bahwa pada tahun 2005 terdapat 567 perkara yang diajukan oleh masyarakat untuk diselesaikan melalui Pengadilan

\footnotetext{
3 Anggarawati dan N.Saidah, "Isu KDRT: Antara Fakta dan Propaganda," Al-Wa'ie, No. 66 Tahun IV, (Februari, 2006), hlm. 10.

4Redaktur, "Pemerintah Belum Begitu Melek terhadap Persoalan KDRT", Kompas, 26 November 2005, hlm. 42.

5 Departemen Kehakiman RI, Laporan Tahunan Perkara yang Diterima dan Diselesaikan. (Pamekasan: Pengadilan Agama: 2005)
} 
Agama. Di antara 567 perkara itu, 274 perkara berbentuk cerai talak dan 277 perkara berbentuk cerai gugat. Dalam istilah lain, dapat dinyatakan bahwa 97,2\% perkara yang diterima untuk ditangani oleh Pengadilan Agama Pamekasan itu didominasi oleh persoalan perceraian sebagai salah satu bentuk penyelesaian yuridis atas kemelut dan problema kerumahtanggaan. Sedangkan $2.8 \%$ sisanya merupakan perkara permohonan atau penetapan hukum. Secara ringkas, laporan tahunan itu diungkapkan pada tabel berikut ini.

Tabel 1

Perkara yang Diterima oleh Pengadilan Agama Pamekasan Tahun 2005.

\begin{tabular}{c|c|c|c}
\hline No. & $\begin{array}{c}\text { Jenis Perkara yang } \\
\text { Diajukan Masyarakat }\end{array}$ & $\begin{array}{c}\text { Jumlah Pengajuan } \\
\text { Perkara }\end{array}$ & $\begin{array}{c}\text { Persentase } \\
\text { Perkara }\end{array}$ \\
\hline 1. & Ijin Poligami & 3 & $0.5 \%$ \\
2. & Cerai Talak & 274 & $48.3 \%$ \\
3. & Cerai Gugat & 277 & $48.9 \%$ \\
4. & Harta Bersama & 1 & $0.2 \%$ \\
5. & Itsbat Nikah & 3 & $0.5 \%$ \\
6. & Wali Adhal & 7 & $1.2 \%$ \\
7. & Kewarisan & 1 & $0.2 \%$ \\
8. & Dispensasi Kawin & 1 & $0.2 \%$ \\
\hline Jumlah perkara keseluruhan & 567 & $100 \%$ \\
\hline
\end{tabular}

Sumber: Adaptasi data dari Departemen Kehakiman RI (2005).

Dalam sajian laporan tahunan itu, terdapat dominasi kuantitas perkara perceraian yang menarik untuk diperhatikan. Kaum istri menampakkan keberanian extraordinary (luar biasa) untuk "memecat" atau "memberhentikan tidak dengan hormat" status pasangan hidupnya sebagai suami dan kepala rumah tangga. Mereka dinilai powerful untuk memutus -batin dalam ikatan sakral yang sengaja telah dijalin bersama secara kukuh (mitsâqan ghalîdhân). Dalam laporan tahunan itu tidak disebutkan secara eksplisit apa penyebab terjadinya cerai talak maupun cerai gugat itu. Kendati pun demikian, dapat dinyatakan bahwa masalah pastinya adalah telah terjadi secara faktual kemelut dan problema dalam kehidupan kerumah-tanggaan di Pamekasan dalam kuantitas yang tergolong sangat tinggi. 
Penyelesaian finalnya adalah pemutusan ikatan perkawinan. Masalah tersebut tidak boleh berhenti atau dihentikan sampai di sini, karena sesungguhnya itulah fenomena dan peristiwa lanjutan dari persoalan fundamental dan esensial yang hingga saat ini belum terungkap dalam rangkaian panjang problema kerumahtanggaan. Jika dicermati secara seksama kasus-kasus perceraian itu, terutama cerai-gugat yang terjadi di kabupaten Pamekasan, sesungguhnya lebih banyak terjadi akibat tindak KDRT dalam segala bentuknya, berupa kekerasan fisik, kekerasan psikis, kekerasan seksual, dan penelantaran rumah tangga. ${ }^{6}$

Informasi hasil penelitian itu cukuplah dapat dijadikan dasarjustifikatif sebagai argumentasi tentang pentingnya kajian ini dilakukan. Oleh karena itu, terlebih dahulu perlu diidentifikasi sebabsebab KDRT terjadi dalam kehidupan rumah tangga, bagaimana bentuknya, siapa atau apa pemicunya, kemungkinan KDRT itu diselesaikan dengan cara-cara lain yang lebih humanistik, selain pemutusan ikatan perkawinan, serta bagaimana penyelesaian yuridisnya. Identifikasi tentang problema KDRT dalam kehidupan rumah tangga di Pamekasan itu perlu memperoleh perhatian serius dan penyelesaian sesegera mungkin karena akan berdampak luas kepada praksis kehidupan sosial kemasyarakatan dan pengamalan nilai-nilai aktual keberagamaan. Atas dasar itulah, kajian ini menampakkan kaitan relevansi dan nilai signifikansi untuk dilakukan.

Melalui penelitian ini diharapkan dapat diungkap secara tuntas penyebab terjadinya kemelut dan problema dalam kehidupan kerumahtanggaan itu, bentuk kemelut dan problema di dalamnya, siapa atau apa yang menjadi pemicunya, siapa pelaku dan siapa korbannya, serta cara-cara lain yang lebih humanistik dalam menyelesaikan problema itu. Hasil penelitian ini diharapkan bermanfaat dan bermakna, sebagai informasi dan balikan khususnya bagi: (a) Ketua dan Majelis Hakim Pengadilan Negeri Pamekasan, tentang ragam dan bentuk kasus-kasus KDRT di Pamekasan agar memperoleh perhatian antisipatif tentang penyelesaian yuridisnya, (b) Para pihak yang terlibat dalam menangani kasus-kasus KDRT,

\footnotetext{
6 Siti Musawwamah, et.al., Cerai gugat di Pengadilan Agama Pamekasan. Laporan Penelitian Kolektif, DIPA-2005 (Pamekasan: STAIN Pamekasan, 2005), hlm. 57.
} 
sebagai pencerahan dan pengayaan wawasan yudisial dalam mencermati proses peradilan, terbitnya putusan perkara, dan eksekusi hasil putusannya, (c) Para akademisi dan Kiai, sebagai informasi tentang realitas tindak KDRT warga Pamekasan, ekses sosiokultural dan sosioreligius, serta penyelesaian yuridisnya, (d) Para peneliti dan pemerhati problema sosial kemasyarakatan khususnya dosen-dosen fakultas/jurusan Syariah, sebagai gambaran tentang hasil kajian dan solusi yuridis atas kasus-kasus KDRT.

\section{Metode Penelitian}

Penelitian ini menggunakan pendekatan hukum normatif dengan jenis penelitian explorative ex-post facto tentang kasus KDRT dan penyelesaiannya, baik melalui proses persidangan maupun di luar persidangan di Pengadilan Negeri. Pilihan pendekatan ini dipandang sesuai karena bahan hukum primer pada kajian utama penelitian ini adalah dokumen-dokumen hukum tertulis, ${ }^{7}$ berupa sejumlah dokumen, arsip pengaduan atau pengajuan kasus/perkara yang diajukan dan/atau diputus oleh lembaga peradilan umum atau Pengadilan Negeri.

Dengan kata lain, penelitian ini dapat juga diistilahkan sebagai kajian isi dokumen perkara (law-documentary content study) sebagai pendekatan utamanya. ${ }^{8}$ Penetapan explorative ex-post facto research sebagai jenis penelitian yang dipilih dalam kajian ini dipandang relevan digunakan berdasarkan argumentasi antara lain, yaitu (a) penelitian ini dilakukan untuk mengeksplorasi fakta hukum yang terjadi pasca-penerbitan UU PKDRT, (b) peneliti tidak melakukan treatment apapun atas fakta dan data yang dikaji karena peristiwanya telah berlangsung, (c) peneliti mengeksplorasi kinerja aparat hukum dalam penerapan norma hukum, kaidah-kaidah hukum, dan aturan perundang-undangan, baik yang menjadi pertimbangan dan landasan hukum aparat dalam menerima dan menindaklanjuti kasus/perkara KDRT pada dokumen yang telah diterbitkan/tersimpan, dan (d)

7 Noeng Muhadjir, Metodologi Penelitian Kualitatif (Yogyakarta: Rake Sarasin, 1989), hlm. 25; Baca juga Soejono \& Abdurrahman, Metode Penelitian Hukum (Jakarta: Rineka Cipta, 2003), hlm. 33; dan Amiruddin \& Zainal Asikin, Pengantar Metode Penelitian Hukum (Jakarta: PT RadjaGrafindo Persada, 2004), hlm. 51.

8 Soerjono Soekanto, Pengantar Penelitian Hukum (Jakarta: UI Press, 1986), hlm. 42; Soejono \& Abdurrahman, Metode Penelitian, hlm. 33. 
Kasus-Kasus Kekerasan dalam Rumah Tangga dan Penyelesaian Yuridisnya

peneliti memeriksa kesesuaian antara isi dokumen dan hasil wawancara dengan sejumlah informan penelitian ini.

Penelitian ini menggunakan orientasi teoretik verstehen paradigm, yaitu suatu perspektif subjektif tentang pengertian interpretatif atas pemahaman fakta, makna, peristiwa dan keterkaitannya dalam situasi tertentu, termasuk di dalamnya adalah produk pikiran manusia dalam bentuk tulisan maupun lisan. ${ }^{9}$ Dengan kata lain, pemaknaannya mengikuti pemahaman dalam bahasa subjek penelitian. Jenis produk tertulis tersebut misalnya berupa buku teks, jurnal, majalah ilmiah, prosiding, dokumen resmi lembaga/publik, dokumen pribadi, personal diary, arsip, artefaks, surat, riwayat hidup tokoh, fotografis, laporan tahunan, dan data statistik. Telaah atas makna dan pemahaman interpretatif subjek penelitian tentang kasus/perkara KDRT, dengan demikian, dapat mewadahi penelitian ini sesuai dengan perspektif teoretik verstehen paradigm. Pemahaman atas makna teks tertulis itu menjadi kajian pokok penelitian ini.

Data yang dihimpun dari dua sumber utama subjek penelitian ini berupa sumber data sekunder, yaitu dokumen tercetak dan sumber data tersier (penunjang). Posisi sumber data penunjang (yang dalam penelitian ini diperlakukan sebagai sumber tersier, walaupun dieksplorasi langsung dari subjek penelitian) merupakan bahanbahan yang memberi petunjuk sebagai acuan atau rujukan atas sumber data sekunder, bahan hukum primer, dan bahan hukum sekunder dalam bentuk konfirmasi para pihak yang terkait dengan kasus/perkara KDRT yang telah diajukan maupun disidangkan oleh majelis hakim lembaga peradilan.

Dalam penelitian ini digunakan tiga jenis bahan hukum, yaitu bahan hukum primer, bahan hukum sekunder, dan bahan hukum tersier. Bahan hukum primer penelitian ini terdiri dari: (1) Dokumen putusan kasus KDRT, (2) UU Nomor 23/2004 tentang PKDRT, (3) UU Nomor 39/ 1999 tentang Hak Asasi Manusia, (4) UU Nomor 5/1998 tentang Konvensi Perlawanan terhadap Penyiksaan dan Perlakuan atau Penghukuman Lain yang Kejam, Tidak Manusiawi, atau

\footnotetext{
9 L.J. Moleong, Metodologi Penelitian Kualitatif (Bandung: Remaja Rosdakarya, 1990),
} hlm. 44 . 
Merendahkan Martabat Manusia. ${ }^{10}$ Bahan hukum sekunder penelitian ini meliputi: (1) Laporan tahunan Pengadilan Negeri pada tahuntahun terakhir atau yang berkaitan dengan KDRT, (2) Jurnal Mimbar Hukum, dan (3) referensi berupa buku-buku tentang teori-teori ilmu hukum. Sedangkan bahan hukum tersier (penunjang/acuan bahan hukum) meliputi: (1) Kamus hukum, (2) Direktori pengadilan, dan (3) referensi atau buku teks Metodologi Penelitian Hukum,

Sejalan dengan desain penelitian ini, data dikumpulkan dengan dua metode. ${ }^{11}$ Pertama, metode non interaktif, yaitu pengumpulan data diarahkan pada akumulasi isi dokumen, arsip, maupun data statistik tentang kasus/perkara KDRT yang tersedia dan/atau diterbitkan oleh Pengadilan Negeri. Data dokumentasi yang menjadi fokus perhatian utama adalah sejumlah berkas pengaduan atau pengajuan kasus/perkara KDRT, produk putusan majelis hakim tentang kasus/perkara KDRT yang telah memiliki kekuatan hukum tetap. Dokumen lainnya diperlakukan sebagai pendukung atau penguat data tentang kasus/perkara KDRT. Kedua, metode interaktif, yaitu pengumpulan data diarahkan pada langkah-langkah konfirmatorik dan eksplanatif atas hasil pelacakan, pembacaan, dan pemahaman isi dokumen. Langkah ini diambil untuk menyamakan persepsi sebagai bahan dalam menjustifikasi perbuatan hukum para pikak yang terlibat kasus/perkara KDRT maupun tindakan majelis hakim dalam merespon persoalan dan menetapkan putusan tentang KDRT.

Pengumpulan data didasarkan pada pedoman yang telah disusun dan dipersiapkan sebelumnya sebagai landasan dalam mengidentifikasi persoalan-persoalan dalam kasus/perkara KDRT. Pedoman tersebut berupa matriks penelitian yang disusun secara operasional, meliputi tema-tema kajian, rincian tema, dan indikator.

10 Presiden RI, Undang-Undang Republik Indonesia Nomor 23 Tahun 2004 tentang Penghapusan Kekerasan Dalam Rumah Tangga (Jakarta: Setneg RI, 2004); Presiden RI, Undang-Undang Republik Indonesia Nomor 39 Tahun 1999 tentang Hak Asasi Manusia (Jakarta: Setneg RI, 1999); Presiden RI, Undang-Undang Republik Indonesia Nomor 5 Tahun 1998 tentang Konvensi Perlawanan terhadap Penyiksaan dan Perlakuan atau Penghukuman Lain yang Kejam, Tidak Manusiawi, atau Merendahkan Martabat Manusia (Jakarta: Setneg RI, 1998).

11 N.K. Denzin, \& Y.S. Lincoln, Handbook of Qualitative Research (Thousand Oaks, California: SAGE Publications, Inc., 1994), hlm. 65; R.K.Yin, Case Studi Research: Design and Methods. (Beverly Hills, CA: Sage Publications, 1996), hlm. 53. 
Penggunaan teknik observasi dalam bentuk pengamatan secara terlibat (participative observation), sebagai bagian dari kegiatan pengumpulan data, tidak digunakan dalam penelitian ini, karena peristiwa hukumnya telah terjadi pada masa yang lalu. Oleh karena itu penggunaan teknik observasi dipandang tidak relevan dilakukan karena penelitian ini tergolong sebagai pengungkapan fakta dan data yang telah terjadi (ex-post facto research). ${ }^{12}$

Data penelitian yang berhasil dikumpulkan kemudian dianalisis dengan menggunakan teknik content analysis pada dokumen utama dan dokumen penunjang. Analisis ini dilakukan melalui proses pelacakan dan pengaturan secara sistematik atas tema-tema konseptual dan indikator yang menjadi fokus perhatian penelitian yang terdapat dalam dokumen. ${ }^{13}$ Data-data tersebut kemudian diinterpretasi sebagai temuan hasil penelitian. Terhadap temuan tersebut dilakukan teknik validitas data melalui teknik konfirmatorik, pembahasan dalam diskusi kolegial, analisis kasus-kasus negatif, dan pelacakan kesesuaian data. ${ }^{14}$

\section{Hasil dan Analisis}

Selama kurun waktu tahun 2005 Pengadilan Negeri Pamekasan telah memeriksa, mengadili, dan memutus tiga kasus KDRT. Dua kasus di antaranya berupa kasus kekerasan fisik sedangkan satu kasus lainnya berupa penelantaran rumah tangga atau kehidupan keluarga. Berikut ini uraian selengkapnya:

\section{Bentuk Kasus-kasus KDRT}

Beberapa bentuk kekerasan fisik oleh para pelaku KDRT di antaranya berupa pemukulan dengan tangan kosong (tanpa menggunakan alat) dan pemukulan dengan menggunakan alat.

\footnotetext{
12 Sugiyono, Metode Penelitian Administrasi (Jakarta: Alfabeta, 1997), hlm. 24.

13 F.N. Kerlinger, 1986. Foundations of Behavioral Research (New York: Holt, Rinehart, and Winston, 1973), hlm 67; E.Babbie, The Practice of Social Reasearch (California: Belmont Publishing Co., 1986), hlm. 77; P.V. Young, Scientific Social Surveys and Research (New Delhi: Prentice-Hall of India, 1982), hlm. 75; Hadari Nawawi, Metode Penelitian Bidang Sosial (Yogyakarta: Gadjah Mada University Press, 1983), hlm. 52; Moleong, Metodologi, hlm. 54.

14 J.P. Goetz, \& M.D. LeCompte,"Ethnographic Research and The Problem of Data Deduction." Anthropology and Education quarterly, Vol. 12 No. 1 (1991), hlm 70.
} 
Kasus-kasus berikut ini menunjukkan realitas faktual tentang kekerasan dalam rumah tangga. Kasus KDRT yang terjadi antara Hariman (41/PNS) dan Wiwiek (bukan nama sebenarnya), misalnya, berupa kekerasan fisik dengan pemukulan langsung tanpa menggunakan alat. Pelaku menempeleng dan memukul korban secara langsung sebanyak 3 (tiga) kali mengenai mulut, pipi kanan, mata, dan hidung serta mendorong korban hingga terjatuh. Akibatnya, korban mengalami luka-luka sebagaimana keterangan dalam visum et repertum dr. R. Budi Santoso/Dokter RSUD Pamekasan No: 445/04/441.441/III/ 2005 tanggal 03 Maretr 2005.

Hasil pemeriksaan dokter menunjukkan bahwa korban dalam kondisi sadar; kepala dan leher bengkak, terjadi pendarahan pada kelopak mata kanan sepanjang $1 / 2 \mathrm{Cm}$, terdapat bekas darah mengering dari hidung kanan kiri dan bibir atas bawah; bahu kanan dan kiri, dada, dan punggung bengkak dan lecet sepanjang $1 \mathrm{Cm}$; dan tidak didapatkan kelainan pada perut dan anggota gerak atas dan bawah.

Kasus KDRT lainnya terjadi antara Sayuti (46/PNS) dan Harifah (bukan nama sebenarnya) berupa kekerasan fisik dengan pemukulan menggunakan alat. Pelaku menempeleng dan memukul korban dengan menggunakan sepotong kayu sepanjang $73,5 \mathrm{~cm}$ dan mengakibatkan korban terluka. Kasus KDRT dalam bentuk Penelantaran Rumah Tangga juga terjadi antara Jalal dengan Hasanah (bukan nama sebenarnya) berupa penelantaran rumah tangga. Pelaku menelantarkan korban (istri dan anaknya) dengan tidak memberi nafkah. Akibatnya, korban pulang dan menjadi tanggungan orang tuanya.

Sebenarnya, dalam menjalani kehidupan rumah tangga, munculnya ketegangan maupun konflik suami istri merupakan hal yang biasa terjadi. Perselisihan pendapat, perdebatan, pertengkaran, saling mengejek atau bahkan memaki pasangan merupakan hal yang umum terjadi. Tetapi semua itu, setelah adanya UU PKDRT dapat menjadi bagian dari bentuk kekerasan dalam rumah tangga yang dapat diproses secara formal melalui peradian. Dalam istilah lain dapat dinyatakan bahwa persoalan KDRT tidak lagi menjadi persoalan privat suami istri, tetapi telah menjadi persoalan publik sebagaimana telah diatur dalam UU PKDRT, yaitu: 
Kasus-Kasus Kekerasan dalam Rumah Tangga dan Penyelesaian Yuridisnya

Setiap orang dilarang melakukan kekerasan dalam rumah tangga terhadap orang dalam lingkup rumah tangganya, dengan cara kekerasan fisik, kekerasan psikis, kekerasan seksual, atau penelantaran rumah tangga (Pasal 5).

Kekerasan fisik sebagaimana dimaksud dalam pasal 5 huruf a adalah perbuatan yang mengakibatkan rasa sakit, jatuh sakit, atau luka berat (Pasal $6)$.

Setiap orang dilarang menelantarkan orang dalam lingkup rumah tangganya, padahal menurut hukum yang berlaku baginya atau karena persetujuan atau perjanjian ia wajib memberikan kehidupan, perawatan atau pemeliharaan keoada orang tersebut (Pasal 9).

\section{Penyebab Terjadinya Kasus-kasus KDRT}

Terjadinya kasus KDRT yang dilakukan oleh suami kepada istri dalam penelitian ini pada umumnya bukanlah merupakan perilaku menyimpang suami yang berdiri sendiri tetapi akumulasi dari beberapa bentuk kasus kekerasan yang lain. Kasus KDRT antara Hariman dan Wiwiek (sebagai pelaku dan korban) disebabkan oleh problema relasi suami istri. Hal ini ditandai oleh perilaku mereka yang belum dapat memosisikan pasangannya sebagai "mitra" hidupnya karena ego masing-masing masih sangat mendominasi kehidupan kerumahtanggaannya. Problema demikian tambah diperparah oleh campur tangan pihak ketiga, yaitu ibu terdakwa karena mereka hidup serumah di rumah ibu terdakwa.

Problema sepele yang biasa terjadi antara menantu dan mertua telah menjadi pemicu terjadinya kasus KDRT oleh suami kepada istri. Saat terjadi perselisihan antara menantu dan mertua, maka suami serta merta membela orang tuanya dan langsung menempeleng dan memukul istrinya (korban) sebanyak 3 (tiga) kali mengenai mulut, pipi kanan, mata dan hidung serta mendorong korban hingga terjatuh. Menyadari perlakuan suami yang dapat mengancam jiwanya, istri (sebagai pelaku KDRT) melaporkannya ke Polres Pamekasan.

Kasus KDRT yang terjadi antara Sayuti dan Harifah disebabkan oleh problema relasi suami istri. Suami merasa sebagai pihak yang dominan/superior dan sebaliknya istri dianggap sebagai pihak yang inferior. Dalam perjalanan hidup suami istri, problema relasi ini 
sering kali menjadi sebab terjadinya kasus-kasus KDRT. Sebagai pihak yang dominan/superior, suami sering menghalalkan segala cara untuk melanggengkan posisinya. Jika terjadi perselisihan atau perbedaan pendapat, maka suami tidak segan-segan menggunakan cara-cara yang dapat dikategorikan sebagai tindakan kekerasan. Saat terjadi perselisihan, suami memukul istri dengan menggunakan sepotong kayu sepanjang 73,5 cm dan mengakibatkan istri terluka. Menyadari perlakuan suami yang dapat membahayakan keselamatan dirinya, sang istri melaporkan suami ke pihak yang berwajib (Polres Pamekasan) sebagai pelaku KDRT.

Kasus KDRT antara Jalal dan Hasinah (sebagai pelaku dan korban) disebabkan oleh problema penetapan tempat kediaman bersama. Masing-masing suami istri bersikukuh pada pendiriannya untuk menentukan tempat kediaman bersama sesuai dengan pilihan dan keinginannya. Sebagai seorang kepala keluarga, suami merasa lebih berhak menentukan tempat kediaman bersama. Demikian juga, istri merasa punya hak memilih sesuai dengan keinginannya, yaitu tetap bersama orang tuanya. Problema ini semakin rumit dan tidak dapat diselesaikan karena ada campur tangan pihak ketiga, yaitu orang tua si istri dengan melarangnya mengikuti keinginan suami karena dalam waktu yang cukup lama sang suami telah meninggalkan kewajibannya sebagai suami, yakni tidak memberi nafkah kepada istri dan anaknya. Akibatnya, semua kebutuhannya ditanggung oleh orang tua dari pihak istri. Menyadari perilaku suami yang tidak bertanggungjawab terhadap nafkah keluarga menyebabkan istri melaporkan suami sebagai pelaku KDRT penelantaran rumah tangga .

Pada umumnya, pemicu atau penyebab terjadinya kasus-kasus KDRT berkaitan erat dengan pola relasi suami istri. Jika masingmasing pihak belum dapat memosisikan pasangannya sebagai "mitra" hidupnya, maka kehidupan rumah tangganya akan rentan terjadi kekerasan. Penyebab kasus-kasus KDRT, terutama yang sering menimpa istri atau para individu perempuan, yaitu faktor eksternal dan faktor internal. Dalam faktor internaldapat dinyatakan bahwa penyebab timbulnya tindak KDRT berkaitan erat dengan problema struktural, seperti pemahaman ajaran agama dan peraturan perundang-undangan, maupun problema kultural, semisal pola relasi 
kekuasaan atau kewenangan suami-istri dan diskriminasi jender dalam kehidupan budaya masyarakat.

Dalam kehidupan masyarakat suamilah yang mempunyai kekuasaan disebabkan posisi inherent mereka sebagai kepala keluarga. Dalam istilah lain, hanya suamilah yang memiliki otoritas, pembuat keputusan, dan memiliki pengaruh terhadap istri dan segenap anggota keluarga dalam kehidupan rumah tangganya. Oleh karena itu dapat dinyatakan bahwa kekuasaan suami dalam lembaga perkawinan terjadi karena penerimaan unsur-unsur kultural yang di dalamnya terdapat norma-norma yang mengakui kepemilikan pengaruh pada posisi khusus kepada suami itu.

Pembedaan peran dan posisi antara suami dan istri di dalam kehidupan berkeluarga dan bermasyarakat diturunkan (diwariskan?) secara kultural kepadanya pada setiap generasi. "Pewarisan kultural" itu bahkan diyakini sebagai ideologi berupa ketentuan Tuhan atau keniscayaan agamawi yang permanen dan tidak bisa diubah. Keyakinan ideologis tersebut berimplikasi pada bagaimana seharusnya perempuan (istri) dan lelaki (suami) itu berpikir, berperilaku, dan bertindak. Hak-hak istimewa (privileges) yang dilekatkan kepada suami - sebagai seorang yang mempunyai kekuasaan lebih tinggi daripada istri- sesungguhnya merupakan produk dari konstruksi sosial. Kenyataan demikian akhirnya menghadirkan diskriminasi atau ketidakadilan peran-peran sosial dan kultural (bias-bias jender). Ketidakadilan akibat bias jender itu ternyata termanifestasi dalam berbagai bentuk, yakni marjinalisasi peran-peran ekonomik, politik, sosial dan budaya, tindak kekerasan, pelabelan (stereotyping), pencapan (stigmating), subordinasi, dan berbagai perlakukan deskriminatif lainnya. ${ }^{15}$

Pada sisi faktor eksternal dapat dinyatakan bahwa penyebab timbulnya tindak KDRT berkaitan erat dengan kondisi psikis dan kepribadian suami. Dalam istilah lain dapat dinyatakan bahwa KDRT yang menimpa kaum perempuan/istri, antara lain, disebabkan oleh: (a) Suami menderita sakit mental, (b) suami pecandu alkohol dan narkoba, (c) ketidakhirauan sebagian anggota masyarakat pada

\footnotetext{
15 Mansour Fakih, “Diskriminasi dan Beban Kerja Perempuan: Perspektif Gender," dalam Binar (ed.), Wacana Perempuan dalam Keindonesiaan dan Kemodernan (Yogyakarta: Pustaka Cidesindo, 1998), hlm. 26-31.
} 
tindak KDRT, (d) arus komunikasi dua arah antara suami dan istri buntu/terhalang, (e) penyelewengan atau perilaku seksual, (f) citra diri yang rendah, (g) frustrasi, (h) perubahan radikal situasi dan kondisi dalam kerumahtanggaan, dan (i) penyelesaian tindak KDRT dengan tindak KDRT serupa.

\section{Penyelesaian Yuridis Kasus-kasus KDRT}

Pengadilan Negeri Pamekasan telah memeriksa dan mengadili 3 kasus KDRT melalui proses persidangan lazimnya kasus-kasus pidana lainnya. Adapun buku rujukan yang dijadikan pedoman adalah Undang-undang No. 23 Tahun 2004 tentang Penghapusan Kekerasan Dalam Rumah Tangga (UU PKDRT). Berikut ini adalah uraian putusan selengkapnya.

Putusan Nomor: 75/Pid.B/2005/PN.Pks, merupakan putusan kasus KDRT antara Hariman dan Wiwiek (sebagai pelaku dan korban) berisi tentang tuntutan Jaksa kepada Majelis Hakim Pengadilan Negeri Pamekasan untuk memberi putusan sebagai berikut:

a) Menyatakan terdakwa HARIMAN bersalah melakukan perbuatan "KEKERASAN FISIK DALAM LINGKUP RUMAH TANGGA" sebagaimana diatur dalam pasal 44 (1) UU RI No.23 Tahun 2004;

b) Menjatuhkan pidana terhadap HARIMAN dengan pidana penjara selama 2 (dua) bulan dikurangi dengan lamanya terdakwa ditahan dengan perintah tetap ditahan;

c) Menetapkan agar terdakwa dibebani membayar biaya perkara sebesar Rp 1.000,-(seribu rupiah)

Kasus KDRT ini merupakan kekerasan fisik dengan pemukulan langsung tanpa menggunakan alat. Pelaku menempeleng dan memukul korban secara langsung sebanyak 3 (tiga) kali mengenai mulut, pipi kanan, mata dan hidung serta mendorong korban hingga terjatuh. Akibatnya, korban mengalami luka-luka sebagaimana keterangan dalam visum et repertum Rumah Sakit Umum Daerah (RSUD) Kabupaten Pamekasan No: 445/04/441.441/III/2005 tanggal 03 Maret 2005, dibuat dan ditandatangani oleh dr. R. Budi Santoso.

Beberapa hal yang menjadi pertimbangan Majelis hakim sebelum menjatuhkan pidana terhadap terdakwa. Hal-hal yang meringankan adalah bahwa terdakwa belum pernah dihukum, terdakwa sopan di persidangan dan mengakui terus terang dan tidak 
berbelit-belit, terdakwa mempunyai beban tanggung jawab kepada Negara selaku Pegawai Negeri Sipil, dan terdakwa menyesali perbuatannya dan tidak akan mengulangi lagi perbuatannya. Sedangkan hal-hal yang memberatkan adalah bahwa perbuatan terdakwa membahayakan jiwa orang lain.

Berdasarkan ketentuan pasal 44 (1) jo (4) UU No. 23 Tahun 2004 tentang PKDRT, majelis hakim mengadili:

a) Menyatakan terdakwa HARIMAN terbukti bersalah melakukan tindak pidana kejahatan;

b) Menjatuhkan pidana terhadap terdakwa tersebut oleh karena itu dengan pidana penjara selama 1 (satu) bulan;

c) Menetapkan bahwa masa penangkapan dan penahanan yang telah dijalani oleh terdakwa dikurangi seluruhnya dari lamanya pidana yang dijatuhkan;

d) Menetapkan supaya terdakwa tetap ditahan;

e) Membebankan piaya perkara sebesar Rp 1.000,- (seribu rupiah) kepada terdakwa.

Putusan Nomor: 138/Pid.B/2005/PN.Pks merupakan putusan kasus KDRT yang terjadi antara Sayuti dan Harifah (sebagai pelaku dan korban). Tuntutan Jaksa kepada Majelis Hakim Pengadilan Negeri Pamekasan sebagai berikut:

a) Menyatakan terdakwa SAYUTI, bersalah melakukan perbuatan "KEKERASAN FISIK DALAM LINGKUP RUMAH TANGGA" sebagaimana diatur dalam pasal 44 (1) UU RI No.23 Tahun 2004;

b) Menjatuhkan pidana terhadap SAYUTI dengan pidana penjara selama 2 (dua) bulan Dengan masa percobaan 4 (empat) bulan;

c) Menyatakan barang bukti sebuah potongan kayu dikemvalikan kepada terdakwa;

d) Menetapkan agar terdakwa dibebani membayar biaya perkara sebesar Rp 1.000,-(seribu rupiah).

Kasus KDRT ini merupakan kekerasan fisik dengan pemukulan menggunakan alat. Pelaku memukul korban dengan sebuah potongan kayu sepanjang $73,5 \mathrm{Cm}$. Beberapa hal yang menjadi pertimbangan Majelis hakim sebelum menjatuhkan pidana terhadap terdakwa. Hal-hal yang meringankan, bahwa: terdakwa belum pernah dihukum, terdakwa sopan di persidangan dan mengakui terus terang dan tidak berbelit-belit, terdakwa mempunyai beban tanggung jawab kepada Negara selaku Pegawai Negeri Sipil, dan 
terdakwa menyesali perbuatannya dan tidak akan mengulangi lagi perbuatannya. Sedangkan hal yang memberatkan adalah bahwa perbuatan terdakwa mengakibatkan luka pada korban.

Berdasarkan ketentuan pasal 44 (1) jo (4) UU No. 23 Tahun 2004 tentang PKDRT, majelis hakim mengadili:

a) Menyatakan terdakwa SAYUTI terbukti bersalah melakukan tindak pidana kejahatan;

b) Menjatuhkan pidana terhadap terdakwa tersebut oleh karena itu dengan pidana penjara selama 1 (satu) bulan;

c) Menetapkan bahwa masa penangkapan dan penahanan yang telah dijalani oleh terdakwa dikurangi seluruhnya dari lamanya pidana yang dijatuhkan;

d) Memerintahkan barang bukti berupa sepotong kayu panjang 73,5 cm dirampas untuk dimusnahkan;

e) Membebankan biaya perkara sebesar Rp 1.000,- kepada terdakwa

Putusan Nomor: 139/Pid.B/2005/PN.Pks, merupakan putusan kasus KDRT yang terjadi antara Jalal dan Hasinah (sebagai pelaku dan korban). Tuntutan Jaksa kepada Majelis Hakim Pengadilan Negeri Pamekasan untuk memberi putusan sebagai berikut:

a) Menyatakan terdakwa JALAL bersalah melakukan perbuatan "KEKERASAN FISIK DALAM LINGKUP RUMAH TANGGA" sebagaimana diatur dalam pasal 49 huruf a jo pasal 9 (1) UU RI No.23 Tahun 2004;

b) Menjatuhkan pidana terhadap JALAL dengan pidana penjara selama 6 (enam) bulan Dengan masa percobaan 10 (sepuluh) bulan;

c) Menyatakan barang bukti berupa kutipan akta nikah nomor 394/05/II/1996 tanggal 5 Pebruari 1996 atas nama JALAL dengan HASINAH dikembalikan kepada saksi HASINAH;

d) Menetapkan agar terdakwa dibebani membayar biaya perkara sebesar Rp 1.000,-(seribu rupiah).

Kasus KDRT ini merupakan penelantaran rumah tangga. Pelaku menelantarkan istri dan anaknya (korban) dengan tidak memberi nafkah. Akibatnya, korban pulang ke rumah orang tuanya dan semua kebutuhannya menjadi tanggungan orang tua.

Beberapa hal menjadi pertimbangan majelis hakim sebelum menjatuhkan pidana terhadap terdakwa. Hal-hal yang meringankan 
bahwa terdakwa belum pernah dihukum, terdakwa sopan di persidangan dan mengakui terus terang dan tidak berbelit-belit, dan terdakwa telah menunjukkan itikat baik kepada korban untuk mau kembali lagi hidup dalam satu rumah tangga namun tidak direspon baik oleh HASINAH. Sedangkan hal yang memberatkan adalah bahwa perbuatan terdakwa mengakibatkan kesengsaraan orang lain.

Berdasarkan ketentuan pasal 49 huruf a jo pasal 9 (1) UU No. 23

Tahun 2004 tentang PKDRT, majelis hakim mengadili:

a) Menyatakan terdakwa JALAL terbukti secara sah dan meyakinkan bersalah melakukan tindak pidana kejahatan "MENELANTARKAN ORANG LAIN DALAM LINGKUP RUMAH TANGGA."

b) Menjatuhkan pidana terhadap terdakwa tersebut oleh karena itu dengan pidana penjara selama 6 (enam) bulan;

c) Menetapkan bahwa pidana tersebut tidak akan dijalankan kecuali apabila di kemudian hari ada perintah lain dari putusan hakim karena terpidana belum lewat masa percobaan selama 10 (sepuluh) bulan melakukan perbuatan yang dapat dipidana;

d) Memerintahkan barang bukti berupa barang bukti berupa kutipan akta nikah nomor 394/05/II/1996 tanggal 5 Pebruari 1996 atas nama JALAL dengan HASINAH dikembalikan kepada saksi HASINAH;

e) Membebankan biaya perkara sebesar Rp 1.000,- kepada terdakwa

Putusan hakim atas kasus-kasus KDRT tersebut berbeda dengan tuntutan jaksa penuntut umum dan apalagi dengan hukuman yang ditetapkan oleh UU PKDRT dan setelah dikonfirmasikan kepada para

hakim yang memeriksa dan mengadili (Bapak Ahmad Subaidi, S.H dan bapak Selamet Riadi, S.H masing-masing sebagai ketua dan anggota majelis hakim) pada prinsipnya berpendapat bahwa:

a) Putusan hakim harus netral, yaitu tidak boleh menunjukkan keberpihakan kepada pihak-pihak yang sedang berperkara di institusi Pengadilan sekalipun berposisi sebagai korban;

b) Para hakim berkeyakinan bahwa adanya kasus-kasus KDRT yang dilakukan oleh para suami pasti tidak muncul secara tiba-tiba, pasti ada pemicu dari para istrinya;

c) Penetapan dan penerapan hukuman oleh majelis hakim kepada para terdakwa tidak dimaksudkan untuk balas dendam atau 
menyengsarakan pihak pelaku sebagai terdakwa tetapi bertujuan untuk mendidik agar di masa mendatang terdakwa tidak melakukan tindak pidana lagi.

Argumen hakim atas penetapan hukumam minimal kepada pelaku KDRT tersebut menunjukkan bahwa:

a) Putusan hakim tidak netral karena hanya memperhatikan kepentingan terdakwa/pelaku;

b) Hakim belum memiliki perspektif jender yang memadai. Adanya keyakinan bahwa tindakan suami (pelaku) karena dipicu oleh tindakan istri (korban) dapat difahami bahwa hakim masih mengokohkan, melanggengkan, dan membenarkan budaya patriarki, yakni dominasi laki-laki atas perempuan atau suami atas istri;

c) Jika penetapan hukuman dimaksudkan untuk memberi efek jera, maka keefektifan pelaksanaannya masih membutuhkan pembuktian yang terus menerus

Sebagai salah satu lembaga pelaksana kekuasaan kehakiman, Pengadilan Negeri mempunyai tugas pokok untuk menerima, memeriksa, dan mengadili serta menyelesaikan setiap perkara yang diajukan kepadanya guna menegakkan hukum dan keadilan berdasarkan Pancasila demi terselenggaranya negara hukum, Republik Indonesia. Oleh karena itu, setiap penetapan atau putusan Pengadilan Negeri harus berkepala Demi Keadilan Berdasarkan Ketuhanan Yang Maha Esa. ${ }^{16}$

Ketentuan tersebut menjadi dasar bahwa keadilan- sebagai intisari penegakan hukum- yang seharusnya diberikan kepada pencari kebenaran dan keadilan, keadaan yang dapat dipertanggungjawabkan di hadapan Allâh swt. atau keadilan yang berdasar Ketuhananan Yang Maha Esa. Keadilan seperti inilah yang seharusnya direfleksikan oleh setiap badan peradilan dan untuk itu diperlukan adanya keberanian hakim untuk menegakkan hukum sebagai refleksi kebenaran dan keadilan. Hukum memang tidak dapat berdiri sendiri, tetapi harus ditegakkan oleh aparat hukum. Salah satu cara penegakan hukum adalah melalui penafsiran perundangundangan yang berlaku sehubungan dengan perkara yang sedang

16 Presiden RI, Undang-Undang Republik Indonesia Nomor 4 Tahun 2004 tentang Kekuasaan kehakiman, Pasal 1 dan 2 (Jakarta: Setneg RI, 2004), hlm. 1. 
ditangani. Bahkan jika diperlukan dalam memutuskan perkara, hakim tidak cukup hanya memegangi ajaran hukum positif yang membatasi diri pada law as it is written in the book ${ }^{17}$ tetapi juga didasari oleh pemikiran yang seimbang dan bijaksana antara hukum dan etika.

Putusaan hakim yang baik harus memenuhi 2 persyaratan, yaitu: Pertama, kebutuhan teoritis, isi dan pertimbangan hukumnya harus dapat dipertanggungjawabkan dari segi ilmu hukum, harus "juridisch en filosofis veraantwoord, bahkan sebagai sebuah yurisprudensi, putusan hakim harus dapat menentukan hukum baru, merupakan sumber hukum. Kedua, kebutuhan praktis, putusan hakim harus dapat menyelesaikan persoalan/sengketa hukum yang ada dan sejauh mungkin dapat diterima oleh pihak-pihak yang bersengketa maupun masyarakat pada umumnya karena dianggap adil, benar, dan berdasarkan hukum. Dengan kata lain, ia dapat diterima secara sosiologis.

Putusan hakim yang sudah dikeluarkan tidak dapat diperbaiki atau ditarik kembali dan mengikat pihak-pihak yang bersangkutan dan dapat dipaksakan berlakunya oleh alat kekuasaan Negara. Ia dianggap sebagai "sabda Pandita Ratu". Oleh karenanya, penetapan putusan hakim harus terlebih dahulu mempertimbangkan segala sesuatunya dari berbagai segi, seobyektif, dan seadil mungkin.

\section{Kesimpulan dan Saran}

Penelitian ini menghasilkan kesimpulan sebagai berikut:

1. Bentuk kasus-kasus KDRT di Pamekasan berupa kekerasan fisik dan penelantaran rumah tangga. Kekerasan fisik itu dilakukan tanpa menggunakan alat dan dengan menggunakan alat. Kasus pertama dalam bentuk kekerasan fisik adalah pelaku menempeleng dan memukul korban secara langsung sebanyak 3 (tiga) kali mengenai mulut, pipi kanan, mata dan hidung serta mendorong korban hingga terjatuh dan mengalami luka-luka. Sedangkan kasus kedua dalam bentuk yang sama adalah pelaku memukul korban dengan sebuah potongan kayu sepanjang 73,5 $\mathrm{cm}$ dan mengakibatkan korban terluka. Sementara untuk kasus

\footnotetext{
17 Soertandyo Wignjosoebroro, HUKUM: Paradigma, Metode, dan Dinamika Masalahnya, Cetakan I (Jakarta: ELSAM dan HUMA, 2000), hlm. 190.
} 
penelantaran rumah tangga adalah pelaku menelantarkan istri dan anaknya (sebagai korban) dengan cara tidak memberi nafkah;

2. Penyebab kasus-kasus KDRT adalah problema relasi suami istri. Dalam kaitan ini, suami belum dapat memosisikan istrinya sebagai "mitra" hidupnya, bahkan suami merasa sebagai pihak yang dominan/superior dan sebaliknya istri dianggap sebagai pihak yang inferior.

3. Penyelesaian yuridis kasus-kasus KDRT menunjukkan putusan yang tidak netral karena hakim hanya memperhatikan kepentingan terdakwa/pelaku. Hakim belum memiliki perspektif jender yang memadai, bahkan masih mengokohkan, melanggengkan, dan membenarkan budaya patriarki/dominasi laki-laki atas perempuan atau suami atas istri.

Berdasarkan tiga rumusan kesimpulan penelitian tersebut, peneliti menyarankan, khususnya bagi: (1) Ketua Pengadilan Negeri Pamekasan, hendaknya memanfaanfaatkan temuan penelitian ini sebagai informasi-balikan, bahan evaluasi, perbaikan performansi, maupun pengambilan berbagai keputusan institusional tentang kinerja internal majelis hakim dengan pembinaan para hakim dalam penanganan dan penyelesaian kasus-kasus KDRT; (2) Majelis Hakim Pengadilan Negeri Pamekasan, hendaknya temuan penelitian ini dijadikan bahan masukan dan evaluasi tentang kinerja para anggota Majelis Hakim dalam proses persidangan dan penetapan hasil-hasil putusan, (3) Para pihak yang terlibat dalam menangani kasus-kasus KDRT, hendaknya memerhatikan pentingnya pencerahan dan pengayaan wawasan yudisial dalam rangkaian proses peradilan kasus KDRT, (4) Para Cendekiawan Muslim (ulama/kiai), hendaknya dapat mendayagunakan informasi proses dan produk peradilan Negeri itu sebagai kasus yang serius dalam KDRT, dan (5) Para akademisi, peneliti, dan pemerhati problema sosial kemasyarakatan khususnya dosen-dosen fakultas/jurusan Syari'ah, agar laporan penelitian ini dapat ditindaklanjuti dalam kegiatan yang lebih operasional sehingga berhasilguna bagi kemaslahatan hidup kerumahtanggaan, terutama yang sedang dalam penyelesaian kasuskasus KDRT. Wallâh a'lam bi al-shawâb.

\section{Daftar Pustaka}


Amiruddin \& Zainal Asikin. Pengantar Metode Penelitian Hukum. Jakarta: PT RadjaGrafindo Persada, 2004.

Anggarawati dan Saidah, N.. "Isu KDRT: Antara Fakta dan Propaganda," Al-Wa'ie, No. 66 Tahun IV, (Februari, 2006).

Babbie, E.. The Practice of Social Reasearch. California: Belmont Publishing Co., 1986.

Denzin, N.K. \& Lincoln, Y.S.. Handbook of Qualitative Research. Thousand Oaks, California: SAGE Publications, Inc., 1994.

Departemen Kehakiman RI. Laporan Tahunan Perkara yang Diterima dan Diselesaikan. Pamekasan: Pengadilan Agama: 2005.

Fakih, Mansour. "Diskriminasi dan Beban Kerja Perempuan: Perspektif Gender," dalam Binar (ed.), Wacana Perempuan dalam Keindonesiaan dan Kemodernan. Yogyakarta: Pustaka Cidesindo, 1998.

Goetz, J.P. \& LeCompte, M.D., "Ethnographic Research and The Problem of Data Deduction." Anthropology and Education Quarterly, 12 (1). (1991)

Kerlinger, F.N. Foundations of Behavioral Research. New York: Holt, Rinehart, and Winston, 1973.

Redaktur. "Pemerintah Belum Begitu Melek terhadap Persoalan KDRT", Kompas, 26 November 2005.

Moleong, L.J., Metodologi Penelitian Kualitatif. Bandung: Remaja Rosdakarya, 1990.

Muhadjir, Noeng. Metodologi Penelitian Kualitatif. Yogyakarta: Rake Sarasin, 1989. 
Siti Musawwamah

Musawwamah, Siti, et.al. Cerai gugat di Pengadilan Agama Pamekasan. Laporan Penelitian Kolektif, DIPA-2005. Pamekasan: STAIN Pamekasan, 2005.

Saidah,N. "KDRT bukan Masalah Jender", Al-Wa'ie, No. 66 Tahun IV (Februari, 2006).

Nawawi, Hadari. Metode Penelitian Bidang Sosial. Yogyakarta: Gadjah Mada University Press, 1983.

Presiden RI. Undang-Undang Republik Indonesia Nomor 23 Tahun 2004 tentang Penghapusan Kekerasan Dalam Rumah Tangga. Jakarta: Setneg RI, 2004.

-------. Undang-Undang Republik Indonesia Nomor 39 Tahun 1999 tentang Hak Asasi Manusia. Jakarta: Setneg RI, 1999).

--------. Undang-Undang Republik Indonesia Nomor 4 Tahun 2004 tentang Kekuasaan kehakiman. Jakarta: Setneg RI, 2004.

--------., Undang-Undang Republik Indonesia Nomor 5 Tahun 1998 tentang Konvensi Perlawanan terhadap Penyiksaan dan Perlakuan atau Penghukuman Lain yang Kejam, Tidak Manusiawi, atau Merendahkan Martabat Manusia.Jakarta: Setneg RI, 1998.

Soejono \& Abdurrahman, Metode Penelitian Hukum. Jakarta: Rineka Cipta, 2003.

Soekanto, Soerjono. Pengantar Penelitian Hukum. Jakarta: UI Press, 1986.

Sugiyono. Metode Penelitian Administrasi. Jakarta: Alfabeta, 1997.

Wignjosoebroro, Soertandyo. HUKUM: Paradigma, Metode, dan Dinamika Masalahnya. Jakarta: ELSAM dan HUMA, 2000.

Yin, R.K. Case Studi Research: Design and Methods. Beverly Hills, CA: Sage Publications, 1996. 
Kasus-Kasus Kekerasan dalam Rumah Tangga dan Penyelesaian Yuridisnya

Young, P.V. Scientific Social Surveys and Research. New Delhi: PrenticeHall of India, 1982. 